\title{
Effects of urea plus nitrate pretreated rice straw and corn oil supplementation on fiber digestibility, nitrogen balance, rumen fermentation, microbiota and methane emissions in goats
}

Xiumin Zhang ${ }^{1,2}$, Rodolfo F. Medrano ${ }^{3,4}$, Min Wang ${ }^{1 *}$, Karen A. Beauchemin ${ }^{5}$, Zhiyuan Ma ${ }^{1,2}$, Rong Wang ${ }^{1,4}$, Jiangnan Wen ${ }^{1,4}$, Lukuyu A. Bernard ${ }^{6}$ and Zhiliang Tan ${ }^{1}$

\begin{abstract}
Background: Urea pretreatment is an efficient strategy to improve fiber digestibility of low quality roughages for ruminants. Nitrate and oil are usually used to inhibit enteric methane $\left(\mathrm{CH}_{4}\right)$ emissions from ruminants. The objective of this study was to examine the combined effects of urea plus nitrate pretreated rice straw and corn oil supplementation to the diet on nutrient digestibility, nitrogen $(\mathrm{N})$ balance, $\mathrm{CH}_{4}$ emissions, ruminal fermentation characteristics and microbiota in goats. Nine female goats were used in a triple $3 \times 3$ Latin Square design ( $27 \mathrm{~d}$ periods). The treatments were: control (untreated rice straw, no added corn oil), rice straw pretreated with urea and nitrate (34 and $4.7 \mathrm{~g} / \mathrm{kg}$ of rice straw on a dry matter [DM] basis, respectively, UN), and UN diet supplemented with corn oil ( $15 \mathrm{~g} / \mathrm{kg}$ soybean and $15 \mathrm{~g} / \mathrm{kg}$ corn were replaced by $30 \mathrm{~g} / \mathrm{kg}$ corn oil, DM basis, UNCO).

Results: Compared with control, UN increased neutral detergent fiber (NDF) digestibility $(P<0.001)$ and copies of protozoa $(P<0.001)$ and $R$. albus $(P<0.05)$ in the rumen, but decreased $N$ retention $(-21.2 \%, P<0.001)$, dissolved hydrogen concentration $(-22.8 \%, P<0.001)$, molar proportion of butyrate $(-18.2 \%, P<0.05)$, (acetate + butyrate) to propionate ratio $(P<0.05)$ and enteric $\mathrm{CH}_{4}$ emissions $(-10.2 \%, P<0.05)$. In comparison with $\mathrm{UN}$, UNCO increased $\mathrm{N}$ retention $(+34.9 \%, P<0.001)$ and decreased copies of protozoa $(P<0.001)$ and methanogens $(P<0.001)$. Compared with control, UNCO increased NDF digestibility $(+8.3 \%, P<0.001)$, reduced ruminal dissolved $\mathrm{CH}_{4}$ concentration $(-24$. $4 \%, P<0.001)$ and enteric $\mathrm{CH}_{4}$ emissions $(-12.6 \%, P<0.05)$.

Conclusions: A combination of rice straw pretreated with urea plus nitrate and corn oil supplementation of the diet improved fiber digestibility and lowered enteric $\mathrm{CH}_{4}$ emissions without negative effects on $\mathrm{N}$ retention. These strategies improved the utilization of rice straw by goats.
\end{abstract}

Keywords: Dissolved hydrogen, Methane, Nitrate, Oil, Rumen fermentation, Urea

\footnotetext{
* Correspondence: mwang@isa.ac.cn

'Key Laboratory for Agro-Ecological Processes in Subtropical Region, National Engineering Laboratory for Pollution Control and Waste Utilization in Livestock and Poultry Production, Institute of Subtropical Agriculture, Chinese Academy of Sciences, Changsha 410125, Hunan, China

Full list of author information is available at the end of the article
}

(c) The Author(s). 2019 Open Access This article is distributed under the terms of the Creative Commons Attribution 4.0 International License (http://creativecommons.org/licenses/by/4.0/), which permits unrestricted use, distribution, and reproduction in any medium, provided you give appropriate credit to the original author(s) and the source, provide a link to the Creative Commons license, and indicate if changes were made. The Creative Commons Public Domain Dedication waiver (http://creativecommons.org/publicdomain/zero/1.0/) applies to the data made available in this article, unless otherwise stated. 


\section{Background}

Rice straw is an abundant crop residue in rice producing areas, such as China and Southeast Asia. However, rice straw has low nutritive value, which limits its wide and efficient use in ruminant diets, because of the high content of indigestible structural polysaccharides and low crude protein $(\mathrm{CP})$ content [1]. Enteric methane $\left(\mathrm{CH}_{4}\right)$ resulting from ruminants is an important source of greenhouse gas and represents a loss of $2-14 \%$ of dietary energy [2]. Feeding straw results in greater $\mathrm{CH}_{4}$ emissions per unit of feed digested than high quality forage, because it has a slow passage rate and prolonged residency time in the rumen [3]. Before promoting the use of rice straw in ruminant diets, strategies are needed to improve its digestibility and decrease its $\mathrm{CH}_{4}$ emissions.

Urea can be used to pretreat rice straw to enhance its nutritional quality by destroying fiber structure and increasing non-protein nitrogen $(\mathrm{N})$ content [1], leading to increased ruminal fiber digestibility $[4,5]$. Nitrate supplementation has been identified as a possible strategy to reduce $\mathrm{CH}_{4}$ emissions $[6,7]$, because nitrate reduction to ammonia incorporates metabolic hydrogen $([\mathrm{H}])$ away from methanogenesis [8]. Urea plus nitrate pretreatment has been reported to increase degradation and reduce $\mathrm{CH}_{4}$ production of rice straw in vitro [9], and further verification of these combined effects in vivo is needed.

Oil supplementation is another option to decrease enteric $\mathrm{CH}_{4}$ emissions from ruminants and improve final quality of product (i.e., milk and meat). Oil supplementation increases energy density of the diet, provides additional unsaturated fatty acids and decreases numbers of protozoa and associated methanogens, but may also decrease ruminal organic matter (OM) fermentation [3]. Additionally, inhibition of ruminal protozoa can decrease microbial $\mathrm{N}$ cycling in the rumen [10] and increase the flow of microbial protein from the rumen to the small intestine [11], leading to an improvement of $\mathrm{N}$ utilization. Thus, oil supplementation of diets containing urea plus nitrate pretreated rice straw may further help to improve efficiency of dietary $\mathrm{N}$ use in ruminants.

In the present study, we hypothesized that pretreatment of rice straw with urea plus nitrate would enhance fiber digestibility and inhibit $\mathrm{CH}_{4}$ production, and supplementation of corn oil to a diet containing the pretreated straw would further exert additional beneficial effects on dietary $\mathrm{N}$ use efficiency and $\mathrm{CH}_{4}$ mitigation. To test these hypotheses, we used goats as the experimental animal, and measured diet digestibility, $\mathrm{N}$ balance, $\mathrm{CH}_{4}$ emissions, rumen fermentation, and selected microorganisms.

\section{Methods}

Urea plus nitrate pretreated rice straw

The rice straw originated from Jiangxi province of China. Whole plant material was obtained and thrashed to remove the grain and the straw was sun-cured and chopped into pieces of approximately $3 \mathrm{~cm}$ in length. Straw was pretreated with urea $(34 \mathrm{~g} / \mathrm{kg}$ straw dry matter $[\mathrm{DM}])$ and $6 \mathrm{~g} /$ $\mathrm{kg} \mathrm{DM}$ of ammonium nitrate (to supply 4.7 nitrate $\mathrm{g} / \mathrm{kg}$ straw DM) for the urea plus nitrate treatment (UN). The pretreatment procedure was fully described by Zhang et al. [9]. Briefly, urea and ammonium nitrate were dissolved in water $(40 \%, w / v)$ and sprayed onto the straw to achieve the appropriate concentrations. The pretreated straw was then placed into sealed $200 \mathrm{~L}$ plastic vessels and incubated at 15 $\pm 3.0^{\circ} \mathrm{C}$ (means $\pm \mathrm{SD}$ ) for 4 weeks. After incubation, the straw was sun-cured for feeding.

\section{Experimental design, goats, and diets}

Nine female Liuyang Black goats (a local breed in southern China, 1 year of age) with body weight of $19.0 \pm 1.22 \mathrm{~kg}$ (mean \pm SD) at the start of the experiment were used. The experiment was a triple $3 \times 3$ Latin Square design with 3 dietary treatments (Table 1). The control diet was formulated to meet appropriately 1.2 to 1.3 times the digestible energy (DE) and CP requirements of non-pregnant female goats according to Zhang and Zhang [12], and consisted of $50 \%$ rice straw and $50 \%$ concentrate (Table 1 ). The UN diet was formulated by replacing untreated rice straw with UN pretreated rice straw. The combination of UN and corn oil supplementation (UNCO) diet was formulated by replacing soybean meal (15 g/kg of dietary DM) and corn grain (15 g/ $\mathrm{kg}$ of dietary DM) with corn oil ( $30 \mathrm{~g} / \mathrm{kg}$ of dietary DM). Goats were fed individually at 07:30 and 17:30 h with equal portions of feed offered at each meal.

The experiment consisted of 3 periods, each with $27 \mathrm{~d}$ including $14 \mathrm{~d}$ for diet adaptation, $5 \mathrm{~d}$ for collecting feces and urine, $6 \mathrm{~d}$ for measuring $\mathrm{CH}_{4}$ emissions and $2 \mathrm{~d}$ for rumen sampling. All goats were housed in individual metabolism cages and had free access to drinking water.

\section{Apparent total-tract digestibility and $\mathrm{N}$ balance}

Total feces and urine were collected and weighed twice daily from d 15 to 19 . A subsample $(\sim 1 \%)$ of feces and urine from each animal was obtained at each collection time and frozen immediately at $-20{ }^{\circ} \mathrm{C}$, and another subsample $(\sim 1 \%)$ was acidified using $10 \%(w / w) \mathrm{H}_{2} \mathrm{SO}_{4}$ to prevent $\mathrm{N}$ loss and then frozen immediately at $-20^{\circ} \mathrm{C}$. The subsamples were then individually combined by day and goat within period. The acidified samples were used for total $\mathrm{N}$ analysis, whereas non-acidified samples were used for other chemical analysis.

The $\mathrm{N}$ balance, including $\mathrm{N}$ excretion and retention, was calculated using the following equations:

$\mathrm{N}$ excretion $(\mathrm{g} / \mathrm{d})=$ fecal $\mathrm{N}(\mathrm{g} / \mathrm{d})+$ urinary $\mathrm{N}(\mathrm{g} / \mathrm{d})$.

$\mathrm{N}$ excretion $(\%)=[\mathrm{N}$ excretion $(\mathrm{g} / \mathrm{d}) / \mathrm{N}$ intake $(\mathrm{g} / \mathrm{d})] \times$ $100 \%$.

$\mathrm{N}$ retention $(\mathrm{g} / \mathrm{d})=\mathrm{N}$ intake $(\mathrm{g} / \mathrm{d})-\mathrm{N}$ excretion $(\mathrm{g} / \mathrm{d})$. 
Table 1 Ingredients and chemical composition of the diets (DM basis)

\begin{tabular}{|c|c|c|c|}
\hline \multirow[t]{2}{*}{ Items } & \multicolumn{3}{|c|}{ Treatment $^{1}$} \\
\hline & Control & UN & UNCO \\
\hline \multicolumn{4}{|l|}{ Ingredients, g/kg } \\
\hline Untreated rice straw ${ }^{2}$ & 500 & - & - \\
\hline Urea plus nitrate pretreated rice straw ${ }^{3}$ & - & 500 & 500 \\
\hline Soybean meal ${ }^{4}$ & 80.0 & 80.0 & 65.0 \\
\hline Corn grain & 292 & 292 & 277 \\
\hline Wheat bran & 98.0 & 98.0 & 98.0 \\
\hline $\mathrm{CaCO}_{3}$ & 1.00 & 1.00 & 1.00 \\
\hline $\mathrm{CaH}_{2} \mathrm{PO}_{4}$ & 4.00 & 4.00 & 4.00 \\
\hline $\mathrm{NaCl}$ & 5.00 & 5.00 & 5.00 \\
\hline Premix & 20.0 & 20.0 & 20.0 \\
\hline Corn oil ${ }^{5}$ & - & - & 30.0 \\
\hline \multicolumn{4}{|l|}{ Chemical composition, g/kg } \\
\hline $\mathrm{OM}$ & 910 & 910 & 921 \\
\hline $\mathrm{CP}$ & 105 & 121 & 119 \\
\hline NDF & 468 & 458 & 440 \\
\hline ADF & 271 & 266 & 257 \\
\hline $\mathrm{GE}, \mathrm{MJ} / \mathrm{kg}$ & 16.2 & 16.3 & 16.3 \\
\hline $\mathrm{EE}$ & 10.2 & 10.2 & 40.2 \\
\hline Nitrate & - & 2.33 & 2.33 \\
\hline
\end{tabular}

${ }^{1}$ UN urea plus nitrate pretreated rice straw, UNCO combination of UN and corn oil

${ }^{2}$ Rice straw contained $898 \mathrm{~g} \mathrm{OM}, 34.4 \mathrm{~g} \mathrm{CP}, 766 \mathrm{~g} \mathrm{NDF}$ and $470 \mathrm{~g}$ ADF per $\mathrm{kg}$ DM

${ }^{3}$ Urea plus nitrate pretreated rice straw contained $898 \mathrm{~g} \mathrm{OM}, 68.1 \mathrm{~g} \mathrm{CP}, 744 \mathrm{~g}$ NDF and $458 \mathrm{~g}$ ADF per $\mathrm{kg} \mathrm{DM}$

${ }^{4}$ Contained $442 \mathrm{~g}$ CP per kg DM

${ }^{5}$ The corn oil was supplied by Wilmar International Ltd., Wuhan, China.

Composed of $15 \%$ saturated fatty acids, $32 \%$ monounsaturated fatty acids and $53 \%$ polyunsaturated fatty acids

$\mathrm{N}$ retention $(\%)=[\mathrm{N}$ retention $(\mathrm{g} / \mathrm{d}) / \mathrm{N}$ intake $(\mathrm{g} / \mathrm{d})] \times$ $100 \%$.

\section{Enteric methane emission}

After total collection, $\mathrm{CH}_{4}$ emissions were measured for 2 $\mathrm{d}$ per goat by moving each goat into a respiration chamber as described by Wang et al. [13]. As only three chambers were available, it took $6 \mathrm{~d}$ (from d 20 to 25) to complete the measurements for all goats. Nine goats were assigned to 3 blocks, with each block containing 3 goats (1 goat from each treatment). The goats in each block were assigned to the same chamber and 1 goat from each block was used for each of the 2-day sequential measurements. The goats were restrained but had free access to a feed bin and drinking water within the chamber. On average, the flow rate of air was maintained at $40 \mathrm{~m}^{3} / \mathrm{h}$. The $\mathrm{CH}_{4}$ concentration in outlet gas from each chamber and ambient gas were measured using an Ultraportable Greenhouse Gas Analyzer (MIU-374-8, Los Gatos Research, San Jose, CA
95134, USA). The cycling time to separately measure $\mathrm{CH}_{4}$ concentration from the 3 chambers was $30 \mathrm{~min}$, with $8 \mathrm{~min}$ for each chamber gas and $6 \mathrm{~min}$ for ambient gas. Calibrations were done by discharging purified $\mathrm{CH}_{4}$ into each chamber at $25 \mathrm{~cm}^{3} / \mathrm{min}$ controlled by a gas flow meter (C100L-CRWE-DD, SIYA Detection Instrument Co., Ltd., Shanghai, China). The gas flow data from both the gas flow meter and chamber were calculated and compared, and then the data for the chamber were adjusted to $100 \%$ recovery according to the data of the gas flow meter. The chambers were opened twice a day at 07:30 and 17:30 $\mathrm{h}$ to deliver the diets, and the chambers were cleaned before the morning feeding.

\section{Rumen sampling}

Rumen contents were collected at $0,2.5$ and $6 \mathrm{~h}$ after morning feeding on 2 consecutive days (d 26 and d 27) using an oral stomach tube according to Wang et al. [13]. About $150 \mathrm{~mL}$ of rumen contents were rapidly collected after discarding the initial $100 \mathrm{~mL}$ of rumen contents. Two subsamples ( $15 \mathrm{~mL}$ each) were immediately frozen at $-80^{\circ} \mathrm{C}$ in liquid nitrogen for DNA extraction and subsequent microbial analysis. Two other subsamples $(35 \mathrm{~mL}$ each) were immediately transferred into $50-\mathrm{mL}$ plastic syringes for measuring dissolved hydrogen $\left(\mathrm{dH}_{2}\right)$ and dissolved $\mathrm{CH}_{4}\left(\mathrm{dCH}_{4}\right)$ concentrations according to the procedures outlined by Wang et al. [14]. About $10 \mathrm{~mL}$ of rumen contents were used for the measurement of ruminal $\mathrm{pH}$ using a portable $\mathrm{pH}$ meter (Starter 300; Ohaus Instruments Co. Ltd., Shanghai, China). An aliquot of 2.5 $\mathrm{mL}$ of rumen contents was centrifuged at $15,000 \times \mathrm{g}$ for 10 min at $4{ }^{\circ} \mathrm{C}$, and supernatant $(1.5 \mathrm{~mL})$ was transferred into tubes containing $0.15 \mathrm{~mL}$ of $25 \%(w / v)$ metaphosphoric acid, vigorously hand-shaken and stored at $-20^{\circ} \mathrm{C}$ for subsequent determination of volatile fatty acid (VFA) and ammonia concentration.

\section{Sample analyses}

The samples of feed, orts and feces were dried in a forced-air oven at $65^{\circ} \mathrm{C}$ for $48 \mathrm{~h}$, ground through a 0.25-mm screen (WJX-100, Shanghai, Yuanwo Company) and analyzed in triplicate for DM, OM, ether extract (EE), neutral detergent fiber (NDF), acid detergent fiber (ADF), $\mathrm{N}$ content and gross energy (GE). The DM (method 930.15), OM (method 942.05), EE (method 963.15) and N (method 970.22) were analyzed according to published methodologies [15]. Neutral detergent fiber and ADF were assayed according to the method of Van Soest et al. [16], and expressed inclusive of residual ash. Heat stable $\alpha$-amylase was added during the NDF analysis. Gross energy was determined using an isothermal automatic calorimeter (5E-AC8018, Changsha Kaiyuan Instruments Co., Ltd., China). Individual VFA concentrations were measured using a gas chromatograph (Agilent 7890, Palo Alto, CA, 
USA) according to the procedure described by Wang et al. [14]. Ammonia-N concentration was measured by UV-Vis spectrophotometer (Shimadzu UV-2450, Kyoto, Japan) according to the protocol described by Chaney and Marbach [17].

\section{Microbial analyses}

Rumen samples taken $2.5 \mathrm{~h}$ after the morning feeding were freeze-dried (CHRIST RVC2-25 CDPIUS, Marin Christ CO., Ltd., Osterode, Germany) for microbial analysis. The DNA was extracted with repeated bead beating plus column purification as described by $\mathrm{Yu}$ and Morrison [18], and eluted by $300 \mu \mathrm{L}$ TE buffer (Tris 10 $\mathrm{mmol} / \mathrm{L}$, EDTA $1 \mathrm{mmol} / \mathrm{L}, \mathrm{pH}=8.0$ ). The quality and quantity of DNA were measured based on absorbance at 260 and $280 \mathrm{~nm}$ using a NanoDrop ND-2000 (NanoDrop Technologies Inc., Wilmington, USA).

The 16S rRNA gene V3-V4 hypervariable regions of bacteria genomic DNA were used for PCR amplification with the primers 5' - ACTCCTACGGGAGGCAGCAG-3' (338F) and 5' - GGACTACHVGGGTWTCTAAT-3' (806R). The PCR reactions were performed in triplicate using a $20-\mu \mathrm{L}$ mixture containing $0.8 \mu \mathrm{L}$ of each primer, $10 \mathrm{ng}$ of template DNA, $2 \mu \mathrm{L} 2.5 \mathrm{mmol} / \mathrm{L}$ dNTPs, $0.4 \mu \mathrm{L}$ of FastPfu polymerase (Transgen, Beijing, China) and $4 \mu \mathrm{L}$ $5 \times$ FastPfu Buffer (Transgen, Beijing, China). The thermal cycling programing was performed as follows: initial denaturation step, $95^{\circ} \mathrm{C}, 3 \mathrm{~min}$; denaturation, 27 cycles, $95^{\circ} \mathrm{C}, 30 \mathrm{~s}$; annealing, $55^{\circ} \mathrm{C}, 30 \mathrm{~s}$; elongation, $72{ }^{\circ} \mathrm{C}, 45 \mathrm{~s}$; and final extension, $72^{\circ} \mathrm{C}, 10 \mathrm{~min}$. The PCR products were excised from $2 \%$ agarose gels and purified using a QIAquick Gel extraction kit (Qiagen, Hilden, Germany). Amplicons from each reaction mixture were quantified fluorometrically, normalized and pooled at equimolar ratios based on the concentration of each amplicon. Amplicons were sequenced with the Illumina MiSeq platform (PE300, Majorbio Bio-Pham Technology, Shanghai, China). Quality control of the sequence reads was performed using MOTHUR v.1.39.5 [19] following the protocol described by Kozich et al. [20]. The high-quality reads were clustered into operational taxonomic units (OTU) at 97\% similarity using Usearch v.7.0 [21]. Representative sequences defined by abundance from each OTU were identified using PyNAST [22] against the SILVA database for bacteria [23]. Taxonomy analysis was performed using the Ribosomal Database Project classifier v.11.1 [24] with a minimum support threshold of $80 \%$. Alpha diversity analyses were generated, including observed species (Sobs), Chao, Ace, Shannon-Weiner, and Simpson's indices. All 16S rRNA gene sequences were deposited into the NCBI Sequence Read Archive under accession number SRP155601.

Real-time quantitative PCR (qPCR) was performed according to the procedures described by Jiao et al. [25]. Briefly, the plasmid DNA containing exact $16 \mathrm{~S}$ or18S rRNA gene inserts were used to make a standard curve for selected microbial groups. All standard curves met the following requirements $\left(R^{2}>0.99,90 \%<E<\right.$ $120 \%)$. The protozoa, fungi, total bacteria, total methanogens, and four selected bacteria were studied. Fibrobacter succinogenes (F. succinogenes), Ruminococcus albus ( $R$. albus) and Ruminococcus flavefaciens ( $R$. flavefaciens) were selected because of their predominant role in fiber digestion [26]; and Selenomonas ruminantium (S. ruminantium) was selected because it plays a role in nitrate and nitrite reduction [27]. Forward and reverse primers of the selected microbial groups are shown in Table 2.

Table 2 Primers for qPCR assay

\begin{tabular}{|c|c|c|c|}
\hline Microbial Species & Primer Sets $\left(5^{\prime} \rightarrow 3^{\prime}\right)$ & Product size, bp & References \\
\hline Protozoa & $\begin{array}{l}\text { F: GCTTTCGWTGGTAGTGTATT; } \\
\text { R: CTTGCCCTCYAATCGTWCT }\end{array}$ & 223 & {$[47]$} \\
\hline Fungi & $\begin{array}{l}\text { F:GAGGAAGTAAAAGTCGTAACAAGGTTC; } \\
\text { R:CAAATTCACAAAGGGTAGGATGATT }\end{array}$ & 121 & {$[48]$} \\
\hline Bacteria & $\begin{array}{l}\text { F: CGGCAACGAGCGCAACCC; } \\
\text { R: CCATTGTAGCACGTGTGTAGCC }\end{array}$ & 146 & {$[48]$} \\
\hline Methanogens & $\begin{array}{l}\text { F: GGATTAGATACCCSGGTAGT; } \\
\text { R: GTTGARTCCAATTAAACCGCA }\end{array}$ & 192 & [49] \\
\hline \multicolumn{4}{|l|}{ Selected groups of bacteria } \\
\hline Fibrobacter succinogenes & $\begin{array}{l}\text { F:GTTCGGAATTACTGGGCGTAAA; } \\
\text { R: CGCCTGCCCCTGAACTATC }\end{array}$ & 121 & {$[48]$} \\
\hline Ruminococcus albus & $\begin{array}{l}\text { F:CCCTAAAAGCAGTCTTAGTTCG; } \\
\text { R: CCTCCTTGCGGTTAGAACA }\end{array}$ & 176 & {$[50]$} \\
\hline Ruminococcus flavefaciens & $\begin{array}{l}\text { F: GAACGGAGATAATTTGAGTTACTTAGG; } \\
\text { R: CGGTCTCTGTATGTTATGAGGTATTACC }\end{array}$ & 132 & {$[48]$} \\
\hline Selenomonas ruminantium & $\begin{array}{l}\text { F: CAATAAGCATTCCGCCTGGG; } \\
\text { R: TTCACTCAATGTCAAGCCCTGG }\end{array}$ & 138 & [51] \\
\hline
\end{tabular}


Table 3 Effect of urea plus nitrate pretreated rice straw (UN) and combination of UN and corn oil supplementation (UNCO) on apparent total-tract digestibility, $\mathrm{N}$ balance and methane emissions in goats

\begin{tabular}{|c|c|c|c|c|c|}
\hline \multirow[t]{2}{*}{ Items } & \multicolumn{3}{|c|}{ Treatment } & \multirow[t]{2}{*}{ SEM } & \multirow[t]{2}{*}{$P$ - value } \\
\hline & Control & UN & UNCO & & \\
\hline DMl, g/d & $484^{b}$ & $501^{a}$ & $496^{\mathrm{ab}}$ & 4.2 & 0.03 \\
\hline \multicolumn{6}{|l|}{ Apparent total-tract digestibility, g/kg } \\
\hline DM & $656^{b}$ & $666^{\mathrm{ab}}$ & $674^{\mathrm{a}}$ & 7.0 & 0.05 \\
\hline $\mathrm{OM}$ & $688^{b}$ & $711^{\mathrm{a}}$ & $720^{a}$ & 10.5 & $<0.001$ \\
\hline NDF & $542^{\mathrm{b}}$ & $577^{\mathrm{a}}$ & $587^{\mathrm{a}}$ & 11.1 & $<0.001$ \\
\hline ADF & 530 & 539 & 538 & 10.9 & 0.62 \\
\hline$C P$ & 631 & 634 & 638 & 14.0 & 0.76 \\
\hline GE & $629^{b}$ & $641^{b}$ & $668^{\mathrm{a}}$ & 12.1 & $<0.001$ \\
\hline \multicolumn{6}{|l|}{ Nitrogen balance } \\
\hline$N$ intake, g/d & $8.41^{c}$ & $9.81^{\mathrm{a}}$ & $9.13^{b}$ & 0.051 & $<0.001$ \\
\hline Urinary N, g/d & $2.94^{\mathrm{b}}$ & $4.35^{\mathrm{a}}$ & $3.32^{\mathrm{b}}$ & 0.198 & $<0.001$ \\
\hline Urinary $\mathrm{N}$ to $\mathrm{N}$ intake ratio, $\%$ & $35.0^{\mathrm{b}}$ & $44.3^{\mathrm{a}}$ & $34.4^{\mathrm{b}}$ & 2.19 & $<0.001$ \\
\hline Fecal N, g/d & $3.10^{\mathrm{b}}$ & $3.60^{\mathrm{a}}$ & $3.30^{\mathrm{b}}$ & 0.141 & $<0.001$ \\
\hline Fecal $\mathrm{N}$ to $\mathrm{N}$ intake ratio, $\%$ & 36.9 & 36.6 & 36.2 & 1.39 & 0.77 \\
\hline N excretion, g/d & $6.05^{b}$ & $7.95^{\mathrm{a}}$ & $6.62^{b}$ & 0.238 & $<0.001$ \\
\hline $\mathrm{N}$ excretion to $\mathrm{N}$ intake ratio, \% & $71.9^{\mathrm{b}}$ & $81.0^{\mathrm{a}}$ & $72.5^{\mathrm{b}}$ & 2.19 & $<0.001$ \\
\hline$N$ retention, $g / d$ & $2.36^{\mathrm{a}}$ & $1.86^{\mathrm{b}}$ & $2.51^{\mathrm{a}}$ & 0.208 & $<0.001$ \\
\hline $\mathrm{N}$ retention to $\mathrm{N}$ intake ratio, $\%$ & $28.1^{\mathrm{a}}$ & $19.1^{b}$ & $27.5^{\mathrm{a}}$ & 2.40 & $<0.001$ \\
\hline \multicolumn{6}{|l|}{ Methane emissions } \\
\hline$g / d$ & $9.91^{\mathrm{a}}$ & $9.24^{\mathrm{ab}}$ & $8.92^{b}$ & 0.779 & 0.04 \\
\hline $\mathrm{g} / \mathrm{kg} \mathrm{DMl}$ & $20.6^{\mathrm{a}}$ & $18.5^{\mathrm{b}}$ & $18.0^{\mathrm{b}}$ & 1.59 & 0.03 \\
\hline $\mathrm{g} / \mathrm{kg} \mathrm{OM}$ digested & $32.8^{\mathrm{a}}$ & $28.5^{\mathrm{b}}$ & $27.3^{b}$ & 2.32 & $<0.001$ \\
\hline $\mathrm{g} / \mathrm{kg}$ NDF digested & $76.3^{\mathrm{a}}$ & $61.2^{\mathrm{b}}$ & $63.7^{b}$ & 4.44 & $<0.001$ \\
\hline$\%$ of GE intake & $6.41^{\mathrm{a}}$ & $5.69^{b}$ & $5.32^{b}$ & 0.481 & 0.004 \\
\hline
\end{tabular}

${ }^{\mathrm{a}-\mathrm{C}}$ Means with different superscripts within a row are significantly different $(P \leq 0.05)$

\section{Statistical analyses}

The statistical analysis was performed using the mixed linear model procedure of SPSS 19.0 (Chicago, IL, USA). Fermentation and $\mathrm{CH}_{4}$ emissions data were averaged to obtain a mean value for the 2 consecutive days before further analysis. For the data of $\mathrm{CH}_{4}$ emissions, digestibility, qPCR, relative abundance and alpha diversity indexes estimated from $16 \mathrm{~S}$ rRNA gene library sequences, the model used included treatment $(n=3)$ as a fixed effect, and period $(n=3)$ and animal $(n=9)$ as random effects. When sampling time was included, the model included dietary treatment $(n=3)$ and the interaction of treatment and sampling time as a fixed effect, sampling time $(n=3)$ as a repeated measurement, and animal $(n=9)$ and period $(n=3)$ as random effects. When significant differences were found, a multiple comparison was conducted to elucidate differences between two particular treatments, and $P$-values were adjusted using the Bonferroni method. Statistical significance was declared at $P \leq 0.05$, with a tendency towards significance declared at $0.05<P \leq 0.10$.

\section{Results}

Goats fed UN diet had a greater dry matter intake (DMI) than control goats $(P=0.03$, Table 3$)$, but DMI of goats fed UNCO was similar to those fed UN and control diets. Total-tract digestibility of OM $(P<0.001)$ and NDF $(P<$ 0.001 ) was greater for goats fed UN or UNCO compared with those fed control diet. However, goats fed UNCO had greater total-tract digestibility of GE than those fed UN $(P<0.001)$ or control diets $(P<0.001)$.

Goats fed UN had greater $\mathrm{N}$ intake $(+16.6 \%, P<0.001)$ and total $\mathrm{N}$ excretion $(+31.4 \%, P<0.001)$, and less $\mathrm{N}$ retention $(-21.2 \%, P<0.001)$ than those fed control (Table 3). In comparison with goats fed UN, those fed UNCO consumed less $\mathrm{N}(-6.9 \%, P<0.001)$ and excreted less $\mathrm{N}$ $(-16.7 \%, P<0.001)$, and retained a greater amount of $\mathrm{N}$ $(+34.9 \%, P<0.001)$. Compared with control, goats fed UNCO had greater N intake $(+8.5 \%, P<0.001)$, but did not differ in $\mathrm{N}$ excretion and retention.

Compared with control, goats fed UN diet had less $(P$ $<0.05$ ) daily $\mathrm{CH}_{4}$ emission expressed as $\mathrm{g} / \mathrm{kg} \mathrm{DMI}, \mathrm{g} / \mathrm{kg}$ 
OM digested, g/kg NDF digested and \% of GE intake (Table 3). Goats fed UNCO also had less $(P<0.05) \mathrm{CH}_{4}$ emissions expressed as $\mathrm{g} / \mathrm{d}$ than those fed the control diet.

Goats fed UN had greater mean ruminal $\mathrm{pH}(P<0.001)$ and ammonia- $\mathrm{N}$ concentration $(+30.8 \%, P<0.05)$, lower $\mathrm{dH}_{2}$ concentration $(-26.8 \%, P<0.001)$, molar proportions of butyrate $(-18.2 \%, P<0.001)$, isobutyrate $(P<0.001)$ and valerate $(P<0.05)$, and (acetate + butyrate) to propionate ratio $(P<0.05)$ in comparison with those fed control (Table 4). Corn oil supplementation to the UN diet decreased mean $\mathrm{pH}(P<0.001)$, and increased molar proportions of butyrate $(+31.7 \%, P<0.001)$ and valerate $(P<$ $0.05)$. Goats fed UNCO had lower $(P<0.001) \mathrm{dCH}_{4}$ concentrations than those fed control or UN. No significant interactions between treatment and sampling time were observed for any of the fermentation variables reported.

Goats fed UN had greater copies of protozoa $(P<0.001)$, methanogens $(P<0.001), R$. albus $(P<0.05)$ and $S$. ruminantium $(P<0.001)$ in comparison with those fed control (Table 5). Corn oil supplementation to the UN diet decreased copies of protozoa $(P<0.001)$, methanogens $(P<$ $0.001)$ and $S$. ruminantium $(P<0.001)$. Goats on all treatments had similar bacterial richness when expressed as Chao and Ace values and as Shannon-Weiner and Simpson indexes (Table 6). However, goats fed UN had greater abundance of Ruminococcaceae $(P<0.001)$ than those fed control, but supplementation of corn oil to the $\mathrm{UN}$ diet decreased the abundance of Ruminococcaceae $(P<0.001)$.

\section{Discussion}

\section{Feed digestibility}

It has been reported that UN pretreatment improved ruminal degradation of rice straw measured in in vitro batch incubation [9]. The present in vivo study also indicates that goats fed UN had greater total-tract digestibility of NDF than those fed control. Urea in the UN pretreatment can be converted to ammonia during incubation with rice straw, which removes the polymerized silica-waxy compounds from the leaf fractions and destroys the covalent association between lignocellulose and exposes the inner tissues to bacterial colonization [28]. Increased in vivo fiber digestibility indicates that UN pretreatment allows greater access of ruminal fibrolytic bacteria to the fiber substrate. Griffith et al. [29] reported that ammoniation of fiber facilitates its degradation by rumen microbes. The rumen has a wide-range of fibrolytic microbial groups that utilize the fibrous substrates in feed. Protozoa and fungi are active fiber degraders, while other predominant fibrolytic bacteria include $R$. albus, $R$. flavefaciens and F. succinogenes [26]. In our study, UN pretreatment increased protozoa and $R$. albus populations, which may have contributed to increased total-tract digestibility of NDF in goats.

Although supplementation of corn oil to the UN diet did not further improve nutrient digestibility, fiber digestibility remained greater than that of the control treatment. It has been reported that high concentrations ( $>40 \mathrm{~g}$ fat $/ \mathrm{kg} \mathrm{DM})$ of fat supplementation exert negative effects on feed digestibility [30]. Thus,

Table 4 Effect of urea plus nitrate pretreated rice straw (UN) and combination of UN and corn oil supplementation (UNCO) on dissolved gases and fermentation end products in the rumen of goats

\begin{tabular}{|c|c|c|c|c|c|c|c|c|c|c|}
\hline \multirow[t]{2}{*}{ Items } & \multicolumn{3}{|c|}{ Treatment } & \multicolumn{3}{|c|}{ Time after morning feeding } & \multirow[t]{2}{*}{ SEM } & \multicolumn{3}{|l|}{$P$ - value } \\
\hline & Control & UN & UNCO & $\mathrm{Oh}$ & $2.5 \mathrm{~h}$ & $6 \mathrm{~h}$ & & Treatment & Time & Treatment $\times$ Time \\
\hline $\mathrm{pH}$ & $6.34^{b}$ & $6.47^{a}$ & $6.33^{b}$ & $6.51^{a}$ & $6.30^{b}$ & $6.34^{b}$ & 0.072 & $<0.001$ & $<0.001$ & 0.42 \\
\hline $\mathrm{NH}_{4}{ }^{+}, \mathrm{mmol} / \mathrm{L}$ & $8.26^{b}$ & $10.8^{\mathrm{a}}$ & $11.2^{\mathrm{a}}$ & 10.9 & 10.8 & 8.6 & 1.31 & 0.02 & 0.06 & 0.58 \\
\hline \multicolumn{11}{|l|}{ Dissolved gases } \\
\hline Dissolved hydrogen, $\mu \mathrm{mol} / \mathrm{L}$ & $0.57^{\mathrm{a}}$ & $0.44^{b}$ & $0.46^{b}$ & $0.30^{c}$ & $0.71^{a}$ & $0.46^{b}$ & 0.038 & $<0.001$ & $<0.001$ & 0.61 \\
\hline Dissolved methane, mmol/L & $1.31^{\mathrm{a}}$ & $1.23^{\mathrm{a}}$ & $0.99^{b}$ & $1.55^{\mathrm{a}}$ & $1.01^{b}$ & $0.96^{\mathrm{b}}$ & 0.067 & $<0.001$ & $<0.001$ & 0.18 \\
\hline Total VFA, mmol/L & 82.3 & 82.1 & 77.5 & $77.4^{\mathrm{b}}$ & $85.6^{a}$ & $79.0^{\mathrm{ab}}$ & 3.73 & 0.15 & $<0.001$ & 0.99 \\
\hline \multicolumn{11}{|c|}{ Molar proportion of individual VFA, mol/100 mol } \\
\hline Acetate & 70.1 & 70.5 & 69.2 & 69.7 & 70.4 & 69.7 & 0.89 & 0.19 & 0.57 & 0.97 \\
\hline Propionate & 19.3 & 20.6 & 19.9 & 19.4 & 20.1 & 20.4 & 0.92 & 0.12 & 0.21 & 0.99 \\
\hline Butyrate & $7.52^{\mathrm{a}}$ & $6.15^{\mathrm{b}}$ & $8.10^{\mathrm{a}}$ & 7.50 & 6.91 & 7.36 & 0.472 & $<0.001$ & 0.28 & 0.72 \\
\hline Iso-butyrate & $1.05^{a}$ & $0.90^{\mathrm{b}}$ & $0.91^{b}$ & $1.16^{\mathrm{a}}$ & $0.85^{\mathrm{b}}$ & $0.84^{b}$ & 0.058 & $<0.001$ & $<0.001$ & 0.77 \\
\hline Valerate & $0.65^{a}$ & $0.57^{b}$ & $0.65^{a}$ & $0.62^{a b}$ & $0.67^{a}$ & $0.59^{b}$ & 0.029 & 0.02 & 0.03 & 0.85 \\
\hline Iso-valerate & 1.40 & 1.21 & 1.31 & $1.66^{\mathrm{a}}$ & $1.13^{b}$ & $1.14^{b}$ & 0.102 & 0.09 & $<0.001$ & 0.96 \\
\hline Acetate/Propionate ratio & 3.83 & 3.50 & 3.66 & 3.73 & 3.67 & 3.59 & 0.20 & 0.06 & 0.58 & 0.99 \\
\hline (Acetate + butyrate)/Propionate ratio & $4.23^{a}$ & $3.82^{b}$ & $4.09^{a b}$ & 4.13 & 4.03 & 3.97 & 0.141 & 0.01 & 0.52 & 0.99 \\
\hline
\end{tabular}

\footnotetext{
${ }^{\mathrm{a}-c}$ Means with different superscripts within a row and heading are significantly different $(P \leq 0.05)$
} 
Table 5 Effect of urea plus nitrate pretreated rice straw (UN) and combination of UN and corn oil supplementation (UNCO) on selected groups of microorganisms ( $\log _{10}$ copies/g DM rumen contents) in the rumen of goats

\begin{tabular}{|c|c|c|c|c|c|}
\hline \multirow[t]{2}{*}{ Items } & \multicolumn{3}{|c|}{ Treatment } & \multirow[t]{2}{*}{ SEM } & \multirow[t]{2}{*}{$P$ - value } \\
\hline & Control & UN & UNCO & & \\
\hline Protozoa & $10.6^{\mathrm{b}}$ & $11.0^{\mathrm{a}}$ & $10.4^{\mathrm{b}}$ & 0.42 & $<0.001$ \\
\hline Fungi & 10.4 & 10.5 & 10.7 & 0.14 & 0.13 \\
\hline Bacteria & 13.7 & 13.8 & 13.6 & 0.10 & 0.36 \\
\hline Methanogens & $12.0^{\mathrm{b}}$ & $12.4^{\mathrm{a}}$ & $12.1^{\mathrm{b}}$ & 0.08 & $<0.001$ \\
\hline \multicolumn{6}{|l|}{ Selected groups of bacteria } \\
\hline Fibrobacter succinogenes & 10.9 & 11.1 & 10.9 & 0.13 & 0.13 \\
\hline Ruminococcus albus & $9.98^{\mathrm{b}}$ & $10.3^{\mathrm{a}}$ & $10.1^{\mathrm{ab}}$ & 0.13 & 0.047 \\
\hline Ruminococcus flavefaciens & 10.2 & 10.1 & 10.1 & 0.10 & 0.34 \\
\hline Selenomonas ruminantium & $12.1^{\mathrm{b}}$ & $12.5^{\mathrm{a}}$ & $12.1^{\mathrm{b}}$ & 0.09 & $<0.001$ \\
\hline
\end{tabular}

${ }^{\mathrm{a}-\mathrm{b}}$ Means with different superscripts within a row are significantly different $(P \leq 0.05)$

the relatively low dose of corn oil (30 g/ $\mathrm{kg}$ DM) supplementation was not expected to decrease fiber digestibility. Similarly, Machmüller and Kreuzer [31] reported that $35 \mathrm{~g}$ oil $/ \mathrm{kg}$ DM supplementation did not alter fiber digestibility in sheep. Although protozoa are major fiber degraders in the rumen [26], the decreased protozoa population observed for UNCO did not negatively affect fiber digestibility.

Table 6 Effect of urea plus nitrate pretreated rice straw (UN) and combination of UN and corn oil supplementation (UNCO) on alpha diversity of bacterial community, and abundance of major phyla (relative abundance $>1 \%$ ) and select families in the rumen of goats

\begin{tabular}{llllll}
\hline Items & \multicolumn{2}{l}{ Treatment } & SEM & $P$ - value \\
\cline { 2 - 4 } & Control & UN & UNCO & & \\
\hline Alpha diversity index & & & & & \\
Number of OTU & 36,693 & 33,587 & 35,882 & 4527 & 0.88 \\
Shannon-Weiner index & 4.02 & 4.04 & 3.59 & 0.339 & 0.38 \\
Simpson index & 0.07 & 0.07 & 0.12 & 0.018 & 0.08 \\
Chao & 786 & 716 & 734 & 79.2 & 0.74 \\
Ace & 777 & 703 & 729 & 77.4 & 0.71 \\
Sobs & 642 & 581 & 567 & 74.9 & 0.66 \\
Relative abundances, \% & & & & & \\
Bacteroidetes & 64.8 & 54.2 & 61.2 & 3.52 & 0.12 \\
Firmicutes & 27.5 & 34.8 & 27.4 & 3.65 & 0.27 \\
Ruminococcaceae & $10.2^{\mathrm{b}}$ & $14.7^{\mathrm{a}}$ & $10.9^{\mathrm{b}}$ & 1.28 & $<0.001$ \\
Spirochaetae & 1.25 & 2.47 & 1.40 & 0.357 & 0.06 \\
Unclassified & 2.14 & 1.72 & 1.24 & 0.711 & 0.69 \\
Others & 4.31 & 6.81 & 8.76 & 0.618 & 0.39 \\
\hline
\end{tabular}

${ }^{a-b}$ Means with different superscripts within a row are significantly different $(P \leq 0.05)$

\section{Nitrogen balance}

The greater $\mathrm{N}$ intake of goats fed $\mathrm{UN}$ did not alter total-tract digestibility of $\mathrm{CP}$, but it increased rumen ammonia- $\mathrm{N}$ concentration and urinary $\mathrm{N}$ excretion, leading to a decrease in $\mathrm{N}$ retention. Djajanegara and Doyle [32] reported that urea pretreatment of rice straw increased fecal $\mathrm{N}$ excretion in sheep. Gunun et al. [5] reported that urea pretreated rice straw increased fecal and urinary $\mathrm{N}$ excretion in dairy cows. The urea and nitrate in the UN pretreatment provided additional non-protein $\mathrm{N}$ for rumen microbes. The lack of treatment effects on $16 \mathrm{~S}$ rRNA gene copies of bacteria would suggest that the additional $\mathrm{N}$ supplied did not promote bacterial growth. It is likely that the soluble protein in the control diet was adequate for microbial growth, and additional $\mathrm{N}$ supplementation did not exert further benefits to the host animals. Furthermore, the greater observed protozoa population for the goats fed UN may have contributed to the decreased capture of ruminal $\mathrm{N}$, resulting in increased ruminal ammonia concentration and urinary $\mathrm{N}$ excretion, because protozoa can prey on bacteria and reduce the amount of $\mathrm{N}$ used for bacterial protein synthesis [10].

Corn oil supplementation to the UN diet decreased $\mathrm{N}$ excretion and increased $\mathrm{N}$ retention. Benchaar et al. [33] reported that $40 \mathrm{~g}$ oil $/ \mathrm{kg} \mathrm{DM}$ reduced $\mathrm{N}$ excretion in dairy cows. Doranalli and Mutsvangwa [34] found that $60 \mathrm{~g}$ oil/kg DM decreased total $\mathrm{N}$ excretion and increased $\mathrm{N}$ retention in growing lambs. Improved $\mathrm{N}$ retention might be due to decreased intra-ruminal $\mathrm{N}$ recycling and increased microbial $\mathrm{N}$ flow to the duodenum [10]. In our study, corn oil supplementation to the UN diet decreased ruminal protozoa numbers, which has been reported to decrease predation of bacteria, and thus facilitate $\mathrm{N}$ capture by bacteria [10]. Therefore, supplementing corn oil to the UN diet offset the negative impact of $\mathrm{UN}$ pretreatment on $\mathrm{N}$ utilization, leading to an improvement of $\mathrm{N}$ retention in goats.

\section{Methane emission and rumen environment}

Enteric $\mathrm{CH}_{4}$ emission was on average $9.9 \pm 1.35 \mathrm{~g} / \mathrm{d}$, which is less than in other studies using goats or sheep. This discrepancy is likely due to the lower body weight (19.0 \pm $1.22 \mathrm{~kg}$ ) of goats used in the present study. Machmüller and Kreuzer [31] reported $29.4 \mathrm{~g} / \mathrm{d} \mathrm{CH}_{4}$ emissions in sheep with body weight of $78 \pm 7.0 \mathrm{~kg}$, while Abecia et al. [35] observed $15.9 \mathrm{~g} / \mathrm{d} \mathrm{CH}_{4}$ emissions in goats with average body weight of $43 \pm 1.7 \mathrm{~kg}$.

The UN treatment greatly decreased $\mathrm{CH}_{4}$ emissions in terms of $\mathrm{g} / \mathrm{kg}$ DMI and $\mathrm{g} / \mathrm{kg}$ OM digested, but did not alter daily $\mathrm{CH}_{4}$ emission in terms of $\mathrm{g} / \mathrm{d}$. This effect is due to the slight increase in DMI and OM digestibility in goats fed the UN diet. Nitrate acts as an alternative hydrogen sink and inhibits $\mathrm{CH}_{4}$ production in the rumen. When compared with control, the observed increase in protozoa 
and S. ruminantium populations for $\mathrm{UN}$ is consistent with the roles of these microorganisms in nitrate and nitrite reduction $[27,36]$. Stoichiometrically, $4 \mathrm{~mol}$ of $2[\mathrm{H}]$ can be redirected to ammonia away from methanogenesis during $1 \mathrm{~mol}$ of nitrate reduction to ammonia $\left(\mathrm{NO}_{3}{ }^{-}+4[2 \mathrm{H}]+\right.$ $2 \mathrm{H}^{+} \rightarrow \mathrm{NH}_{4}{ }^{+}+3 \mathrm{H}_{2} \mathrm{O}$ ), equivalent to $258.1 \mathrm{~g} \mathrm{CH}_{4} / \mathrm{kg}$ nitrate. If $2.33 \mathrm{~g}$ nitrate $/ \mathrm{kg}$ dietary $\mathrm{DM}$ in $\mathrm{UN}$ was completely reduced to ammonia, $\mathrm{CH}_{4}$ reduction would have been $0.6 \mathrm{~g} / \mathrm{kg}$ DMI. However, the observed $\mathrm{CH}_{4}$ reduction of $2.1 \mathrm{~g} / \mathrm{kg}$ DMI is far more than that theoretical reduction. Toxic effects of nitrate and nitrite have been reported for methanogens, but the dietary nitrate content $(2.33 \mathrm{~g} /$ $\mathrm{kg} \mathrm{DM})$ in the present study is far less than that in published studies (6.7 and $5.3 \mathrm{~g} / \mathrm{kg} \mathrm{DM}$, respectively) [7, 27], indicating that toxic effects may not have been the main cause of $\mathrm{CH}_{4}$ reduction for the UN treatment.

The shift of rumen fermentation may contribute to the $\mathrm{CH}_{4}$ reduction for the UN treatment. The decreased butyrate molar proportion and (acetate + butyrate) to propionate ratio of the goats fed $\mathrm{UN}$ is consistent with the decrease in $\mathrm{CH}_{4}$ emission of $\mathrm{UN}$ compared with control. Acetate and butyrate formation results in net $[\mathrm{H}]$ production, while propionate formation incorporates $[\mathrm{H}]$ [37]. A shortage of $[\mathrm{H}]$ would result in reduced methanogenesis. Our previous in vitro study found that urea plus nitrate pretreatment for rice straw decreased $\mathrm{CH}_{4}$ production with a reduction of acetate to propionate ratio [9]. van Zijderveld et al. [38] observed that nitrate supplementation caused $\mathrm{CH}_{4}$ inhibition, which was accompanied by increased propionate molar proportion at the expense of acetate and butyrate.

Oil supplementation inhibits $\mathrm{CH}_{4}$ production [39], due to a reduction in $\mathrm{OM}$ intake, rumen fermentation and protozoa associated methanogens. Guyader et al. [40] reported that a combination of $40 \mathrm{~g}$ linseed oil $/ \mathrm{kg}$ dietary $\mathrm{DM}$ and $30 \mathrm{~g}$ calcium nitrate/ $\mathrm{kg}$ dietary DM shows additive effects on $\mathrm{CH}_{4}$ mitigation. However, we did not find additive effects on $\mathrm{CH}_{4}$ mitigation when corn oil was supplemented to the UN diet. Therefore, the combination of $\mathrm{UN}$ and corn oil supplementation effectively decreases $\mathrm{CH}_{4}$ emissions, but not to a greater extent than $\mathrm{UN}$ alone.

As nitrate acts as an electron acceptor in anaerobic environments, reduction of nitrate to ammonia is associated with decreased $\mathrm{H}_{2}$ availability for methanogens [41]. However, nitrate or nitrite may exert toxic effect on methanogens, leading to an increase in ruminal $\mathrm{H}_{2}$ accumulation or $\mathrm{dH}_{2}$ concentration [39]. The balance between nitrate reduction and nitrite toxicity determines the available $\mathrm{H}_{2}$ in the rumen. In our study, UN treatment decreased ruminal $\mathrm{dH}_{2}$ concentration, indicating that nitrate in $\mathrm{UN}$ treatment incorporates $[\mathrm{H}]$ for ammonia synthesis during nitrate reduction. The low nitrate content $(2.33 \mathrm{~g} / \mathrm{kg}$ dietary DM) of the UN treatment was unlikely to have been toxic to the methanogens. Urea plus nitrate treatment did not alter $\mathrm{dCH}_{4}$ concentration, possibly because increased DMI and NDF digestibility can cause greater $\mathrm{CH}_{4}$ synthesis. When compared with control, goats fed UNCO had lower $\mathrm{dCH}_{4}$ concentration in rumen fluid, which is consistent with decreased $\mathrm{CH}_{4}$ emissions. However, in comparison with control, UNCO increased the fiber digestibility and ruminal ammonia concentration, but did not alter major individual VFA profile. These results are surprising and the underlying mechanism needs further investigation.

\section{Bacterial community}

Urea plus nitrate treatment did not alter diversity of bacterial community, as shown by the similar Shannon-Weiner and Simpson indexes between UN and control groups. Bacteroidetes and Firmicutes are the two predominant phylums in the rumen bacterial community [42]. Although UN did not alter abundances of these phyla in comparison with control, the large increase in abundance of Ruminococcaceae family, which plays a very important role in fiber degradation [43], is consistent with the observed increase in fiber digestibility [44]. The greater $16 \mathrm{~S}$ rRNA gene copies of $R$. albus of goats fed UN compared with control goats is consistent with the literature. Nguyen et al. [4] fed swamp buffaloes rice straw pretreated with urea plus limestone (20 $+20 \mathrm{~g} / \mathrm{kg} \mathrm{DM}$ of rice straw) and reported an increase in $16 \mathrm{~S}$ rRNA gene copies of $R$. albus. It seems that the urea component in the UN treatment destroys the indigestible structural polysaccharide matrix, which facilitates coloniz ation of fibrolytic bacteria by providing attachment sites for adherence of the bacteria. When corn oil was supplemented to the UN diet, abundance of Ruminococcaceae family was reduced, indicating that the unsaturated fatty acids in the oil had negative effects on microbiota of the rumen [45]. High-fat diets can decrease the abundance of Ruminococcaceae family [46]. When compared with control, UNCO did not alter bacterial diversity and abundance of major dominant bacteria and 16S rRNA gene copies of selected bacteria. Thus, it appears that corn oil supplementation can reverse the negative effects of UN on bacteria, resulting in a similar bacterial community as the control group.

\section{Conclusions}

Urea plus nitrate pretreated rice straw increased total-tract fiber digestibility and decreased $\mathrm{CH}_{4}$ emissions but with decreased $\mathrm{N}$ retention. Greater fiber digestibility was associated with increased protozoa and $R$. albus populations and greater abundance of Ruminococcaceae. The urea in the UN pretreatment destroyed the covalent association between lignocellulose and exposed the inner tissues for attachment of fibrolytic microorganisms. Nitrate in the UN pretreatment appeared to incorporate $[\mathrm{H}]$ away from methanogenesis, leading to a reduction in ruminal $\mathrm{dH}_{2}$ 
concentration and methanogenesis. Supplementation of corn oil to the UN diet increased $\mathrm{N}$ retention, which may have been due to the decreased protozoa population. Compared with the control group, UNCO treatment increased fiber digestibility and decreased $\mathrm{CH}_{4}$ emissions, although most of the selected ruminal microorganisms were not changed. A combination of UN pretreatment and corn oil supplementation improved fiber digestibility and decreased $\mathrm{CH}_{4}$ emissions without affecting $\mathrm{N}$ balance, and thus may provide a potential strategy to increase nutritive value of rice straw for ruminant production.

\section{Abbreviations \\ [H]: Metabolic hydrogen; ADF: Acid detergent fiber expressed inclusive of residual ash; $\mathrm{CH}_{4}$ : Methane; $\mathrm{CP}$ : Crude protein; $\mathrm{dCH}_{4}$ : Dissolved methane; DE: Digestible energy; $\mathrm{dH}_{2}$ : Dissolved hydrogen; DM: Dry matter; DMI: Dry matter intake; EE: Ether extract; F. succinogenes: Fibrobacter succinogenes; GE: Gross energy; N: Nitrogen; NDF: Neutral detergent fiber expressed inclusive of residual ash; OM: Organic matter; qPCR: Real-time quantitative polymerase chain reaction; $R$. albus: Ruminococcus albus; $R$. flavefaciens: Ruminococcus flavefaciens; S. ruminantium: Selenomonas ruminantium; UN: Urea plus nitrate treatment; UNCO: UN diet supplemented with corn oil; VFA: Volatile fatty acid}

\section{Acknowledgements}

Not applicable.

\section{Funding}

This work was supported by National Natural Science Foundation of China (Grant No. 31561143009 and 31472133), National Key Research and Development Program of China (Grant No. 2016YFD0500504 and 2018YFD0501800), State Key Laboratory of Animal Nutrition (Grant No. 2004DA125184F1705), China Agriculture Research System (Grant No. CARS36), Major Project of Hunan Province (Grant No. 2017NK1020), Youth Innovation Promotion Association CAS (Grant No.2016327), CAS President's International Fellowship (Grant No. 2018VBA0031), Open Fund of Key Laboratory of Agroecological Process in Subtropical Region, Chinese Academy of Science (Grant No. ISA2017304).

\section{Availability of data and materials}

All data generated or analyzed during this study are included in this published article.

\section{Authors' contributions \\ $X Z, M W, Z T$ and LB designed research; XZ, RM, ZM, RW and JW conducted research; $X Z$ and $M W$ analyzed data; $X Z, K B$ and $M W$ wrote the paper. All authors read and approved the final manuscript and take full responsibility for the final content.}

\section{Ethics approval and consent to participate}

All animal procedures used in this study were reviewed and approved by the Animal Care Committee (Approval number: ISA-Wang-201,705), Institute of Subtropical Agriculture, the Chinese Academy of Sciences, Changsha, China.

\section{Consent for publication}

Not applicable.

\section{Competing interests}

The authors declare no competing interests.

\section{Author details}

'Key Laboratory for Agro-Ecological Processes in Subtropical Region, National Engineering Laboratory for Pollution Control and Waste Utilization in Livestock and Poultry Production, Institute of Subtropical Agriculture, Chinese Academy of Sciences, Changsha 410125, Hunan, China. ${ }^{2}$ University of the Chinese Academy of Sciences, Beijing 100049, China. ${ }^{3}$ College of Veterinary Science and Medicine, Central Luzon State University, Science City of Muñoz,
3120 Nueva Ecija, Philippines. ${ }^{4}$ College of Animal Science and Technology, Hunan Agricultural University, Changsha 410128, People's Republic of China. ${ }^{5}$ Agriculture and Agri-Food Canada, Lethbridge Research and Development Centre, Lethbridge, Alberta T1J 4B1, Canada. ${ }^{6}$ International livestock Research Institute, POB 30709, Nairobi 00100, Kenya.

Received: 1 August 2018 Accepted: 4 January 2019

Published online: 23 January 2019

\section{References}

1. Sarnklong C, Cone JW, Pellikaan W, Hendriks WH. Utilization of rice straw and different treatments to improve its feed value for ruminants: a review. Asian-Aust J Anim Sci. 2010;23:680-92.

2. Beauchemin KA, Kreuzer M, O'Mara F, McAllister TA. Nutritional management for enteric methane abatement: a review. Aust J Exp Agr. 2008;48:21-7.

3. McAllister TA, Cheng KJ, Okine EK, Mathison GW. Dietary, environmental and microbiological aspects of methane production in ruminants. Can J Anim Sci. 1996;76:231-43.

4. Nguyen VT, Wanapat M, Khejornsart P, Kongmun P. Nutrient digestibility and ruminal fermentation characteristic in swamp buffaloes fed on chemically treated rice straw and urea. Trop Anim Health Prod. 2012;44:629-36.

5. Gunun P, Wanapat M, Anantasook N. Effects of physical form and urea treatment of rice straw on rumen fermentation, microbial protein synthesis and nutrient digestibility in dairy steers. Asian-Aust J Anim Sci. 2013;26:1689-97.

6. van Zijderveld SM, Gerrits WJ, Dijkstra J, Newbold JR, Hulshof RB, Perdok HB. Persistency of methane mitigation by dietary nitrate supplementation in dairy cows. J Dairy Sci. 2011;94:4028-38.

7. Olijhoek DW, Hellwing AL, Brask M, Weisbjerg MR, Hojberg O, Larsen MK, et al. Effect of dietary nitrate level on enteric methane production, hydrogen emission, rumen fermentation, and nutrient digestibility in dairy cows. J Dairy Sci. 2016;99:6191-205.

8. Latham EA, Anderson RC, Pinchak WE, Nisbet DJ. Insights on alterations to the rumen ecosystem by nitrate and nitrocompounds. Front Microbiol. 2016;7:228.

9. Zhang X, Wang M, Wang R, Ma Z, Long D, Mao H, et al. Urea plus nitrate pretreatment of rice and wheat straws enhances degradation and reduces methane production in in vitro ruminal culture. J Sci Food Agric. 2018;98:5205-11.

10. Jouany JP. Effect of rumen protozoa on nitrogen utilization by ruminants. J Nutr. 1996;126:1335S-46S.

11. Veira DM, Ivan M, Jui PY. The effect of ciliate protozoa on the flow of amino acids from the stomach of sheep. Can J Anim Sci. 1984;64:22-3.

12. Zhang HF, Zhang ZY, Animal nutrition parameters and feeding standard. China Agriculture Press. China: Beijing; 1998.

13. Wang $M$, Wang $R$, Zhang $X$, Ungerfeld EM, Long $D$, Mao $H$, et al. Molecular hydrogen generated by elemental magnesium supplementation alters rumen fermentation and microbiota in goats. Br J Nutr. 2017;118:401-10.

14. Wang $M$, Wang $R$, Janssen $P H$, Zhang $X M$, Sun $X Z$, Pacheco $D$, et al. Sampling procedure for the measurement of dissolved hydrogen and volatile fatty acids in the rumen of dairy cows. J Anim Sci. 2016;94:1159-69.

15. Association of Official Analytical Chemists (AOAC). Official methods of analysis, 18th ed. Assoc. Off. Anal. Chem. Int., Gaithersburg, MD; 2005.

16. Van Soest PJ, Robertson JB, Lewis BA. Symposium: carbohydrate methodology, metabolism and nutritional implications in dairy cattle. Methods for dietary fiber, neutral detergent fiber, and nonstarch polysaccharides in relation to animal nutrition. J Dairy Sci. 1991;74:3583-97.

17. Chaney AL, Marbach EP. Modified reagents for determination of urea and ammonia. Clin Chem. 1962;8:130-2.

18. Yu Z, Morrison M. Improved extraction of PCR-quality community DNA from digesta and fecal samples. BioTechniques. 2004;36:808-12.

19. Schloss PD, Westcott SL, Ryabin T, Hall JR, Hartmann M, Hollister EB, et al. Introducing mothur: open-source, platform-independent, communitysupported software for describing and comparing microbial communities. Appl Environ Microbiol. 2009;75:7537-41.

20. Kozich JJ, Westcott SL, Baxter NT, Highlander SK, Schloss PD. Development of a dual-index sequencing strategy and curation pipeline for analyzing amplicon sequence data on the MiSeq Illumina sequencing platform. Appl Environ Microbiol. 2013;79:5112-20.

21. Edgar RC. UPARSE: highly accurate OTU sequences from microbial amplicon reads. Nat Methods. 2013;10:996-8. 
22. Caporaso JG, Bittinger K, Bushman FD, DeSantis TZ, Andersen GL, Knight R. PyNAST: a flexible tool for aligning sequences to a template alignment. Bioinformatics. 2010;26:266-7.

23. Quast C, Pruesse E, Yilmaz P, Gerken J, Schweer T, Yarza P, et al. The SILVA ribosomal RNA gene database project: improved data processing and webbased tools. Nucleic Acids Res. 2013:41:D590-6.

24. Wang Q, Garrity GM, Tiedje JM, Cole JR. Naive Bayesian classifier for rapid assignment of rRNA sequences into the new bacterial taxonomy. Appl Environ Microbiol. 2007;73:5261-7.

25. Jiao J, Wang P, He Z, Tang S, Zhou C, Han X, et al. In vitro evaluation on neutral detergent fiber and cellulose digestion by post-ruminal microorganisms in goats. J Sci Food Agric. 2014;94:1745-52.

26. Wang Y, McAllister TA. Rumen microbes, enzymes and feed digestionareview. Asian-Aust J Anim Sci. 2002;15:1659-76.

27. Asanuma N, Yokoyama S, Hino T. Effects of nitrate addition to a diet on fermentation and microbial populations in the rumen of goats, with special reference to Selenomonas ruminantium having the ability to reduce nitrate and nitrite. Anim Sci J. 2015;86:378-84.

28. Saha BC. Hemicellulose bioconversion. J Ind Microbiol Biotechnol. 2003;30: 279-91.

29. Griffith CL, Ribeiro GO Jr, Oba M, McAllister TA, Beauchemin KA. Fermentation of ammonia fiber expansion treated and untreated barley straw in a rumen simulation technique using rumen inoculum from cattle with slow versus fast rate of fiber disappearance. Front Microbiol. 2016;7:1839.

30. McGinn SM, Beauchemin KA, Coates T, Colombatto D. Methane emissions from beef cattle: effects of monensin, sunflower oil, enzymes, yeast, and fumaric acid. J Anim Sci. 2004;82:3346-56.

31. Machmüller A, Kreuzer M. Methane suppression by coconut oil and associated effects on nutrient and energy balance in sheep. Can J Anim Sci. 1999:79:65-72.

32. Djajanegara A, Doyle PT. Urea supplementation compared with pretreatment.2. Effects on ruminal and post-ruminal digestion in sheep fed a rice straw. Anim Feed Sci Technol. 1989;27:31-47.

33. Benchaar C, Hassanat F, Martineau R, Gervais R. Linseed oil supplementation to dairy cows fed diets based on red clover silage or corn silage: effects on methane production, rumen fermentation, nutrient digestibility, $\mathrm{N}$ balance, and milk production. J Dairy Sci. 2015;98:7993-8008.

34. Doranalli K, Mutsvangwa T. Feeding sunflower oil to partially defaunate the rumen increases nitrogen retention, urea-nitrogen recycling to the gastrointestinal tract and the anabolic use of recycled urea-nitrogen in growing lambs. Br J Nutr. 2011;105:1453-64.

35. Abecia L, Toral PG, Martin-Garcia Al, Martinez G, Tomkins NW, MolinaAlcaide $E$, et al. Effect of bromochloromethane on methane emission, rumen fermentation pattern, milk yield, and fatty acid profile in lactating dairy goats. J Dairy Sci. 2012;95:2027-36.

36. Yang C, Rooke JA, Cabeza I, Wallace RJ. Nitrate and inhibition of ruminal Methanogenesis: microbial ecology, obstacles, and opportunities for lowering methane emissions from ruminant livestock. Front Microbiol. 2016;7:132.

37. Janssen PH. Influence of hydrogen on rumen methane formation and fermentation balances through microbial growth kinetics and fermentation thermodynamics. Anim Feed Sci Technol. 2010;160:1-22.

38. van Zijderveld SM, Fonken B, Dijkstra J, Gerrits WJ, Perdok HB, Fokkink W, et al. Effects of a combination of feed additives on methane production, diet digestibility, and animal performance in lactating dairy cows. J Dairy Sci. 2011;94:1445-54.

39. Beauchemin KA, McAllister TA, McGinn SM. Dietary mitigation of enteric methane from cattle. $C A B$ reviews: perspectives in agriculture, veterinary science, nutrition and natural. Resources. 2009;4:1-18.

40. Guyader J, Eugene M, Meunier B, Doreau M, Morgavi DP, Silberberg M, et al. Additive methane-mitigating effect between linseed oil and nitrate fed to cattle. J Anim Sci. 2015;93:3564-77.

41. Ungerfeld EM, Kohn RA, The role of thermodynamics in the control of ruminal fermentation. In Ruminant Physiology, ed. By Sejrsen K, Hvelpund T and Nielsen MO, Wageningen academic publishers, Wageningen, The Netherlands; 2006. p. 55-85.

42. Martinez-Fernandez G, Denman SE, Yang C, Cheung J, Mitsumori M, McSweeney CS. Methane inhibition alters the microbial community, hydrogen flow, and fermentation response in the rumen of cattle. Front Microbiol. 2016;7:1122.
43. Mao S, Zhang M, Liu J, Zhu W. Characterising the bacterial microbiota across the gastrointestinal tracts of dairy cattle: membership and potential function. Sci Rep. 2015;5:16116.

44. Thoetkiattikul H, Mhuantong W, Laothanachareon T, Tangphatsornruang S, Pattarajinda V, Eurwilaichitr $L$, et al. Comparative analysis of microbial profiles in cow rumen fed with different dietary fiber by tagged 165 rRNA gene pyrosequencing. Curr Microbiol. 2013;67:130-7.

45. Maia MR, Chaudhary LC, Figueres L, Wallace RJ. Metabolism of polyunsaturated fatty acids and their toxicity to the microflora of the rumen. Anton Leeuw Int J G. 2007;91:303-14.

46. Daniel H, Gholami AM, Berry D, Desmarchelier C, Hahne H, Loh G, et al. Highfat diet alters gut microbiota physiology in mice. ISME J. 2014;8:295-308.

47. Sylvester JT, Karnati SK, Yu Z, Morrison M, Firkins JL. Development of an assay to quantify rumen ciliate protozoal biomass in cows using real-time PCR. J Nutr. 2004;134:3378-84.

48. Denman SE, MCSweeney CS. Development of a real-time PCR assay for monitoring anaerobic fungal and cellulolytic bacterial populations within the rumen. FEMS Microbiol Ecol. 2006;58:572-82.

49. Hook SE, Wright AD, McBride BW. Methanogens: methane producers of the rumen and mitigation strategies. Archaea. 2010;2010:945785.

50. Koike S, Kobayashi Y. Development and use of competitive PCR assays for the rumen cellulolytic bacteria: Fibrobacter succinogenes, Ruminococcus albus and Ruminococcus flavefaciens. FEMS Microbiol Lett. 2001;204:361-6.

51. Stevenson DM, Weimer PJ. Dominance of Prevotella and low abundance of classical ruminal bacterial species in the bovine rumen revealed by relative quantification real-time PCR. Appl Microbiol Biotechnol. 2007;75:165-74.

\section{Ready to submit your research? Choose BMC and benefit from:}

- fast, convenient online submission

- thorough peer review by experienced researchers in your field

- rapid publication on acceptance

- support for research data, including large and complex data types

- gold Open Access which fosters wider collaboration and increased citations

- maximum visibility for your research: over $100 \mathrm{M}$ website views per year

At BMC, research is always in progress.

Learn more biomedcentral.com/submissions 